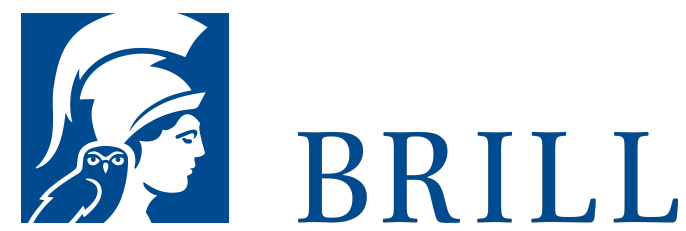

\title{
Yearbook International Tribunal for the Law of the Sea / Annuaire Tribunal international du droit de la mer, Volume $12(2008)$
}

Authors: International Tribunal for the Law of th and Tribunal international du Droit de la me

The International Tribunal for the Law of the Sea is an independent judicial body established by the United Nations Convention on the Law of the Sea to adjudicate disputes arising out of the interpretation and application of the Convention. The Tribunal is open to States Parties to the Convention. It is also open to entities other than States Parties (States and international organizations non-parties to the Convention and natural or juridical persons) in cases provided for in the Convention or other agreements conferring jurisdiction on the Tribunal.

The Yearbook - Annuaire will give lawyers, scholars, students as well as the general public access to information about the jurisdiction, procedure and organization of the Tribunal and also about its composition and activities in 2008. The Yearbook is prepared by the Registry of the Tribunal. Until 2007, it was published in two separate volumes, English (Yearbook) and French (Annuaire). The Yearbook - Annuaire 2008 is the first bilingual volume.

Le Tribunal international du droit de la mer est un organe judiciaire indépendant, créé par la Convention des Nations Unies sur le droit de la mer, pour connaître des différends auxquels pourraient donner lieu l'interprétation et l'application de la Convention. Le Tribunal est ouvert aux Etats Parties à la Convention. Il est également ouvert à des entités autres que les Etats...

See More

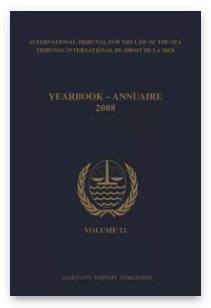

Pages: 562 pp.

Language:

English

Subjects: Law of the Sea, International Law, International Organizations, International Law

Publisher: Brill | Nijhoff

Series:

Yearbook

International

Tribunal for the

Law of the Sea /

Annuaire

Tribunal

international du droit de la mer,

Volume: 12

E-Book (PDF)

Released online: ${ }_{15}$ Aug 2009

ISBN: $978-90-$

47-41215-1

Paperback

Publication date: o7 Aug 2009

ISBN: 978-9004-17065-O List price 
For more information see brill.com

Order information: Order online at brill.com +44 330333 o049 | customerservices@brill.com Submission information: brill.com/authors

Titles published by Brill | Fink, Brill | mentis or Brill | Schöningh: +49(o)71 5413279216 | brill@brocom.de 